\title{
Effects of Schistosomal Mansoni Infection on Calomys callosus Coelom-associated Lymphomyeloid Tissue (Milky Spots)
}

\author{
Jane A Lenzi $/^{+}$, Marcelo Pelajo-Machado/ ${ }^{++}$, Ester M Mota, Denise N \\ Oliveira, Mônica S Panasco/ ${ }^{+++}$, Zilton A Andrade* , Henrique L Lenzi
}

Departamento de Patologia, Instituto Oswaldo Cruz Av. Brasil 4365, 21045-900 Rio de Janeiro, RJ, Brasil

*Centro de Pesquisas Gonçalo Moniz-Fiocruz, Rua Valdemar Falcão 121, 40295-001 Salvador, BA, Brasil

Calomys callosus Rengger, 1830 (Rodentia: Cricetidae) is a mouse-like South American wild rodent, which is permissive to Schistosoma mansoni infection. In this paper we studied the effect of schistosomal infection in $\mathrm{C}$. callosus mesenteric and omental milky spots $(\mathrm{MS})$, subsidiary foci of coelom-associated lymphomyeloid tissue (CALT), during the acute, transitional (acute to chronic), and chronic phases of the infection. MS were morphologically analyzed by histological methods, using brigthfield and confocal laser scanning microscopies. The MS of infected animals were mainly of lymphomyelocytic (42 to 90 days) and lymphoplasmacytic (160 days of infection) types and showed frequent presence of lymphoid follicles with germinal centers, plasmacytogenesis and plasmacytosis, mastocytosis, megakaryopoiesis, erythropoiesis and less pronounced eosinopoiesis. These results indicate that MS are a preferential site of germinal-center-dependent and independent plasmacytogenesis, and a bone marrow-like organ, committed with various cellular lineages. The consequence of $\mathrm{C}$. callosus MS reactivity for schistosomal infection is still unknown and is under investigation.

Key words: Calomys callosus - coelom-associated lymphomyeloid tissue (CALT) - Schistosoma mansoni - milky spots - omentum - laser confocal microscopy

We have shown that Schistosoma mansoni strongly activate the murine mesenteric and omental milky spots (MS) (Weinberg et al. 1992, Lenzi et al. 1992, 1996). These organoid structures were first described by von Recklinghausen (1863) as white spots in the omentum of rabbits. They have also been observed in human omentum (Seifert 1921, Kampmeier 1928, Mixter 1941, Shimotsuma et al. 1989, 1991, Krist et al. 1995) and in several animals: cattle, chicken, frog, guinea pig (Hamazaki 1925), bat (Eptesicus fuscus), cat, dog, gray squirrel (Sciurus carolinensis), ground squirrel (Citellus tridicemlineatus), mole (Scalopus aquaticus), mouse, rat (Mixter 1941), pig (Trebichavski et al. 1981), goat, sheep (Brandt \& Schnorr 1983) and athymic mouse (Burger et al. 1996).

However, there is no report on Calomys callosus Rengger, 1830 (Rodentia: Cricetidae) MS.

\footnotetext{
This work was supported by Papes-fiocruz and CNPq. ${ }^{+}$Corresponding author. Fax: +55-21-598.4466. E-mail: jarnt@gene.dbbm.fiocruz.br

${ }^{++}$CAPES fellowship, ${ }^{+++}$FAPERJ researcher.

Received 4 May 1998

Accepted 31 August 1998
}

This animal is a mouse-like South American wild rodent (Hershkovitz 1962, Massoia \& Fornes 1965) and is a permissive host to $S$. mansoni infection (Borda 1972, Coelho et al. 1979, Mello 1979/80, Lenzi et al. 1995).

C. callosus presents peculiar reactional aspects to $S$. mansoni infection lacking, in the liver, histopathological signs of hypersensitivity, without being an athymic animal (Lenzi et al. 1995). It seems to utilize preferably, in inflammatory rections provoked by $S$. mansoni products, more ancestral cells (macrophages, granulocytes, mast cells), phylogenetically derived from coelo-mocytes. In fact, MS represent subsidiary foci of coelom-associated lymphomyeloid tissue (CALT) (Lenzi et al. 1996).

$S$. mansoni adult worms live in mesenteric vessels, and consequently, their released products can reach the mesenteric and omental microcirculation, being a CALT activator.

For these reasons, we studied the morphological characteristics and the reactivity patterns of CALT in S. mansoni infected C. callosus.

\section{MATERIALS AND METHODS}

Fourty-four $C$. callosus were percutaneously infected with $70 \mathrm{~S}$. mansoni cercariae when they were five days old, and killed on the following days after infection: 42 (6 animals), 55 (9 animals), 90 (14 animals), 160 (14 animals) and 229 (1 animal). 
Twelve non-infected $C$. callosus matched in age with the animals 55 and 160 days of infection were used as controls (6 animals/point). Lungs, liver, intestines, spleen and pancreas fragments were removed from all animals to evaluate the level and characteristics of the infection, while the entire mesenterium, greater and pancreaticosplenic omenta were removed. All tissue samples were fixed in Carson's modified Millonig's phosphatebuffered formalin, $\mathrm{pH} 7.4$ (Carson's formalinMillonig) (Carson et al. 1973) and embedded in paraffin. Histological sections of all organs were stained with hematoxylin-eosin (H \& E). Additional stains were applied to mesenteries and omenta, such as Lennert's Giemsa (Lennert 1978) and Gomori's reticulin stains for brightfield microscopy and phosphomolybdic acid-picrosirius red (PMA-PSR) (collagen) (Dolber \& Spach 1993), Sirius red pH 10.2 (eosinophils) (Bogomoletz 1980, Luque \& Montes 1989, Vale et al. 1997), Masson's trichrome (plasma cells), and Alcian blue/safranin (mast cell subpopulation) (Strobel et al. 1981) for confocal laser scanning microscopy (CLSM). In 15 animals with 55, 90 and 160 days of infection, the mesenteries were distended using an intraintestinal spiral copper wire and also fixed in Carson's formalin-Millonig and stained with Lennert's Giemsa for $2 \mathrm{hr}$. After staining, the mesenteries were separated from the intestines with scissors, and the leaflets, usually three, were mounted, after two xylenes baths, with Gum Damar and coverslip. One distended mesentery was desiccated in incubator $\left(37^{\circ} \mathrm{C}, 1 \mathrm{hr}\right)$, and analyzed in scanning electron microscopy (SEM)-lowvacuum mode (LEO 435-VP).

Cryostat large omentum (and spleen) sections of two infected C. callosus (55 and 160 days of infection) and two controls were studied by direct immunofluorescence using FITC conjugated monoclonal antibodies against mouse CD5, TCR ab, TCR gd, CD 23, CD 45 (B220) (PharMingen, San Diego, CA, USA) and FITC-conjugated polyclonal antibodies against IgM, IgG and IgA (Sigma Chemical Co., St. Louis, MO, USA). In five animals, the pleural membrane that centrally divides the thoracic cavity was also isolated, fixed, embedded in paraffin, and the sections were stained with H\&E, Lennert's Giemsa and Sirius red pH 10.2.

\section{RESULTS}

Mesenterium leaflets (not sectioned, prepared with spiral copper wire and stained with Lennert's Giemsa) from non-infected $C$. callosus showed mast cells in rows, close to the large and small vessels (arteries, veins and lymphatics) of the trabecular connective and adipose tissues (Figs 1-3). They also presented few and isolated MS (some- times rich in mast cells) and clean (free of inflammatory cells), transparent and thin membranes between trabeculae (Figs 1, 4, 5). Otherwise, the mesenteries of infected animals $(55,90$ and 160 days of infection) presented intense and diffuse cellularity, mainly constituted by monocytes, neutrophils and mast cells. The mast cells were more numerous nearby greater and lesser vessels and inside MS, and sometimes were diffusely spread all over the mesenterium leaflets (Fig. 6). The vascular network, even in the mesenteric membranes, became exacerbated (Figs 10,11). Dense and long lymphocytic perivascular sheaths were detected in limited segments of veins (Figs 7, 8). MS became greater and more numerous due to an increment in their cellularity (Figs 8, 9, 12). They can take different forms such as marginal and non-marginal sessile, papillary and cordonal (Figs 8-13). Some MS displayed a dense cellular core surrounded by a layer of spread cells (Fig. 13).

Highly activated MS, in histological studies, were noticed either in mesenteries as in omenta, at all stages of infection. They were composed of abundant lymphocytes, diffuselly distributed or arranged in perivascular sheaths (Fig. 14) or forming clusters of lymphoblastoid cells (Fig. 15). These cells formed pseudofollicular aggregates and defined, from 90 days of infection onwards, distinct germinal centers in the second phase of development, consisting mostly of centroblasts, some in mitosis. Germinal centers also presented phagocytosis centers containing apoptotic cellular residua (Figs 16, 17). One MS of 229 days S. mansoni infected $C$. callosus expressed several germinal centers, acquiring a lymph node-like aspect (Fig. 18). MS presented also foci of plasmacytogenesis, numerous mature plasma cells (Fig. 19), with Russel bodies (Fig. 20), which were sometimes periarterially disposed. There was frequent megakaryopoiesis (Fig. 21) and erythropoiesis foci (Fig. 22), with few and limited areas of eosinopoiesis (Figs 23, 24) and rare neutrophils. Eosinopoiesis foci were more exuberant at 42 days of infection (Fig. 23). Large and numerous safranin positive mast cells were localized below the mesothelial surface (Figs 25-27). The mesothelial cells were usually hypertrophic (type II) (Fig. 28), and fibroblasts and mainly macrophages were the predominant stromal cells. On 160 days after infection, MS frequently enclosed lymphatic vessels, full of median size lymphocytes. MS stroma was made of a diffuse and delicate mesh of reticular (Fig. 29), and collagen picrosirius-positive fibers. The fibers were situated mainly under the mesothelial surface or around the vessels (Fig. 30). Such fibers were found to connect the mesenteric milky spots to the stromal network of the mesenteric membranes (Figs 32, 33). 
Intravascular S. mansoni eggs and small periovular granulomas were sometimes seen (Fig. 31). Omental MS of control animals were essentially composed by small lymphocytes, macrophages, mast cells and plasma cells.
Pleural MS findings, in infected animals, were more monotonous than the omental ones, and were constituted by numerous mast cells, lymphocytes, plasma cells, monocytes/macrophages and few eosinophils.
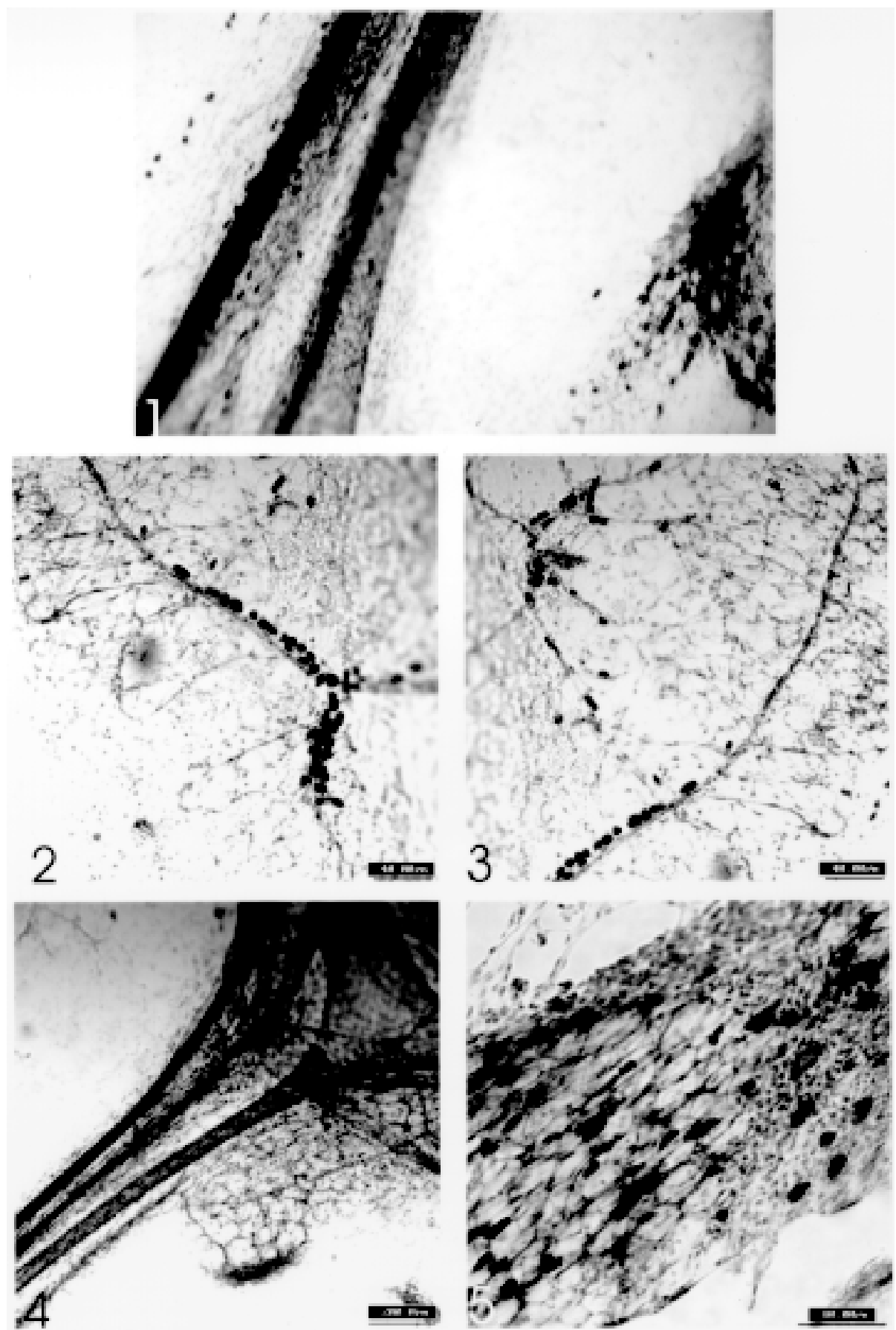

Fig. 1: mesenterium of control (non-infected) Calomys callosus, showing membranes devoid of cellular infiltrate, a small milky spot (MS) rich in mast cells, and mast cells concentrated close to the trabecular vessels (Lennert's Giemsa, X 80). Figs 2, 3: rows of mast cells localized mainly in the bifurcation of the vascular branches that irrigate the fat pads (non-infected) (Lennert's Giemsa, bar $=40 \mathrm{~mm}$ ). Fig. 4: small marginal MS (non-infected) (Lennert's Giemsa, bar $=200 \mathrm{~mm}$ ). Fig. 5: MS rich in mast cells (noninfected) (Lennert's Giemsa, bar $=80 \mathrm{~mm}$ ). 

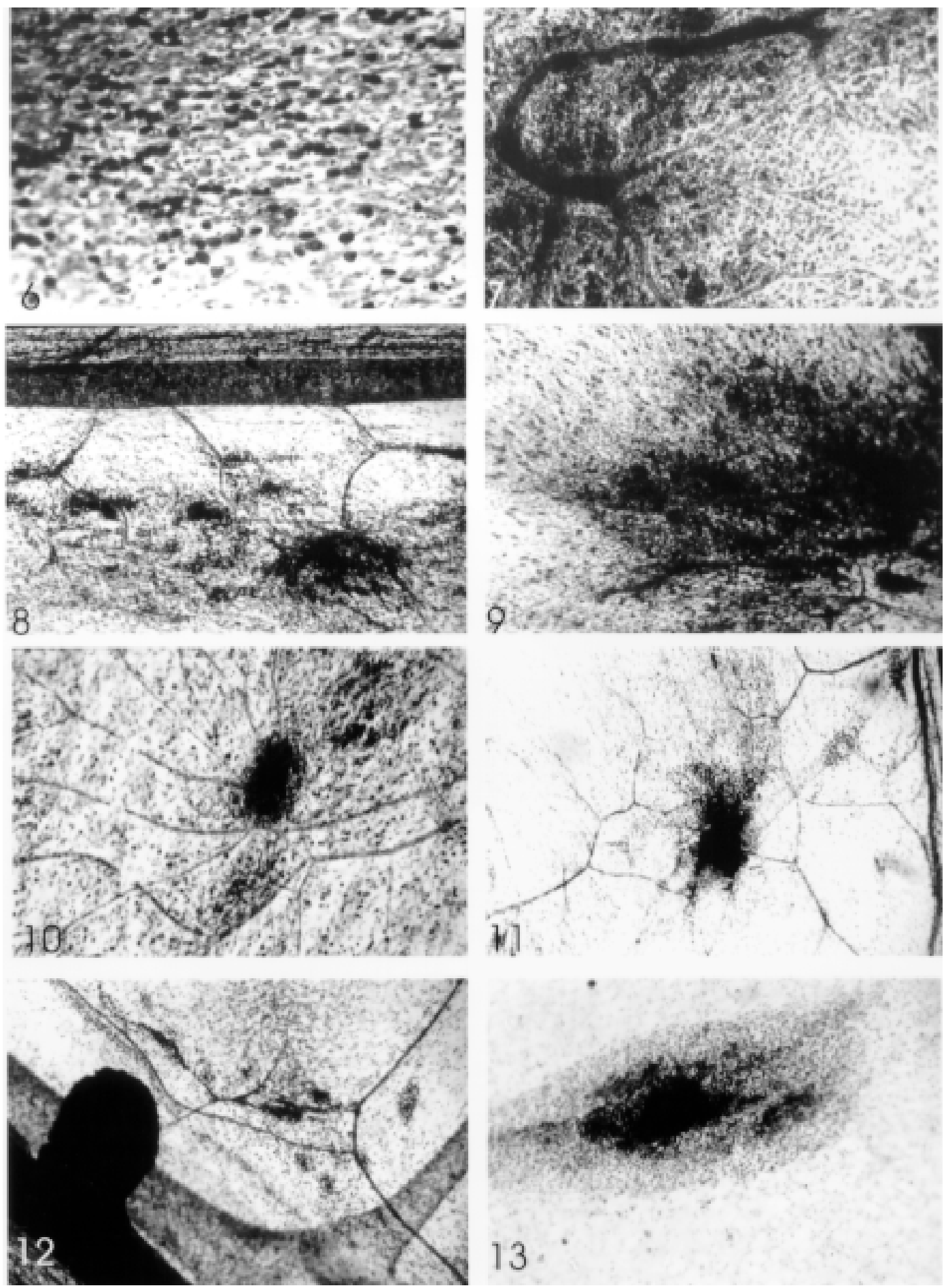

Fig. 6: diffuse cellular infiltrate on mesenteric membrane with numerous mast cells. Time of infection: 160 days (Lennert's Giemsa, X 200). Fig. 7: long and thick perivascular cellular sheath together with massive justavascular infiltration of cells. Time of infection: 160 days (Lennert's Giemsa, X 100). Fig. 8: increased number of marginal sessile milky spots (MS). Time of infection: 160 days (Lennert's Giemsa, X 80). Fig. 9: large and expanded MS with many adjacent mast cells. Time of infection: 160 days (Lennert's Giemsa, X 80). Figs 10, 11: non-marginal MS connected with exarcebated vascular network in mesenteric membranes. Time of infection: 160 days [Lennert's Giemsa, X 100 (Fig. 10); X 80 (Fig. 11)]. Fig. 12: tiny and neoformed marginal MS close a larger one with non-pedunculated papillary aspect. Time of infection: 160 days (Lennert's Giemsa, X 80). Fig. 13: MS with cellular core and peripheral area. Time of infection: 90 days (Lennert's Giemsa, X 100). 

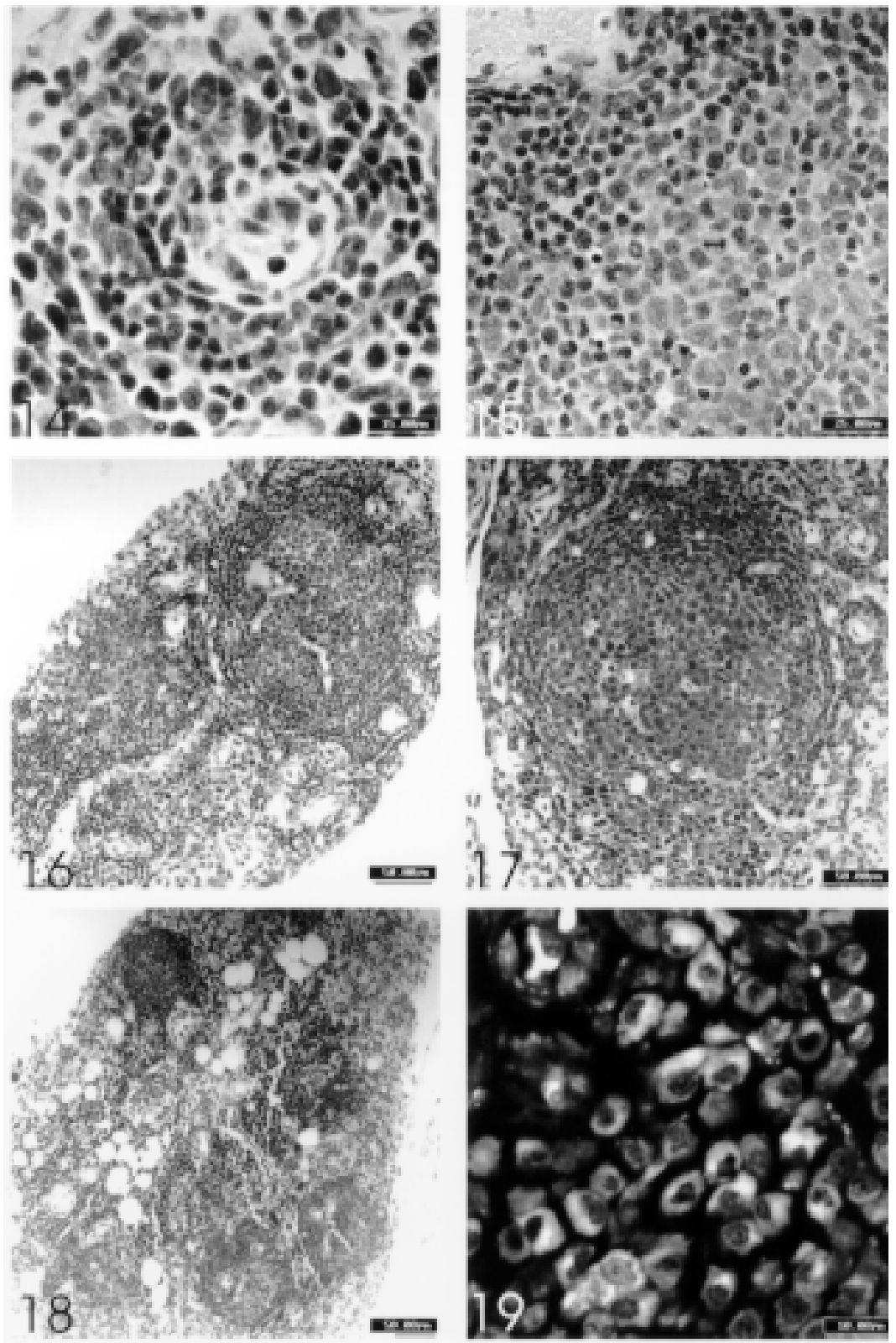

Fig. 14: lymphocytic perivenular infiltrate containing some immunoblastic cells (transformed lymphocytes). Time of infection: 160 days $(\mathrm{H} \& \mathrm{E}$, bar $=15 \mathrm{~mm})$. Fig. 15: centroblast aggregate characterizing the beginning of a germinal center. Time of infection: 55 days $(\mathrm{H} \& \mathrm{E}$, bar $=25 \mathrm{~mm})$. Figs 16, 17: lymphocytic MS showing follicles with germinal centers (second phase of development) sharply demarcated from mantle zone ("corona"). Time of infection: 160 days (Fig. 16) and 90 days (Fig. 17) $(\mathrm{H} \& \mathrm{E}, \mathrm{bar}=50 \mathrm{~mm})$. Fig. 18: MS with a lymph node-like aspect, presenting a cortical layer with several lymphoid follicles with germinal center. Time of infection: 229 days $(H \& E$, bar $=50 \mathrm{~mm}$ ). Fig. 19: area of MS rich in mature plasma cells whose cytoplasm reflected the $543 \mathrm{~nm} \mathrm{He} / \mathrm{Ne}$ laser. Time of infection: 160 days (Masson's Trichrome, bar = $10 \mathrm{~mm}$ ). 

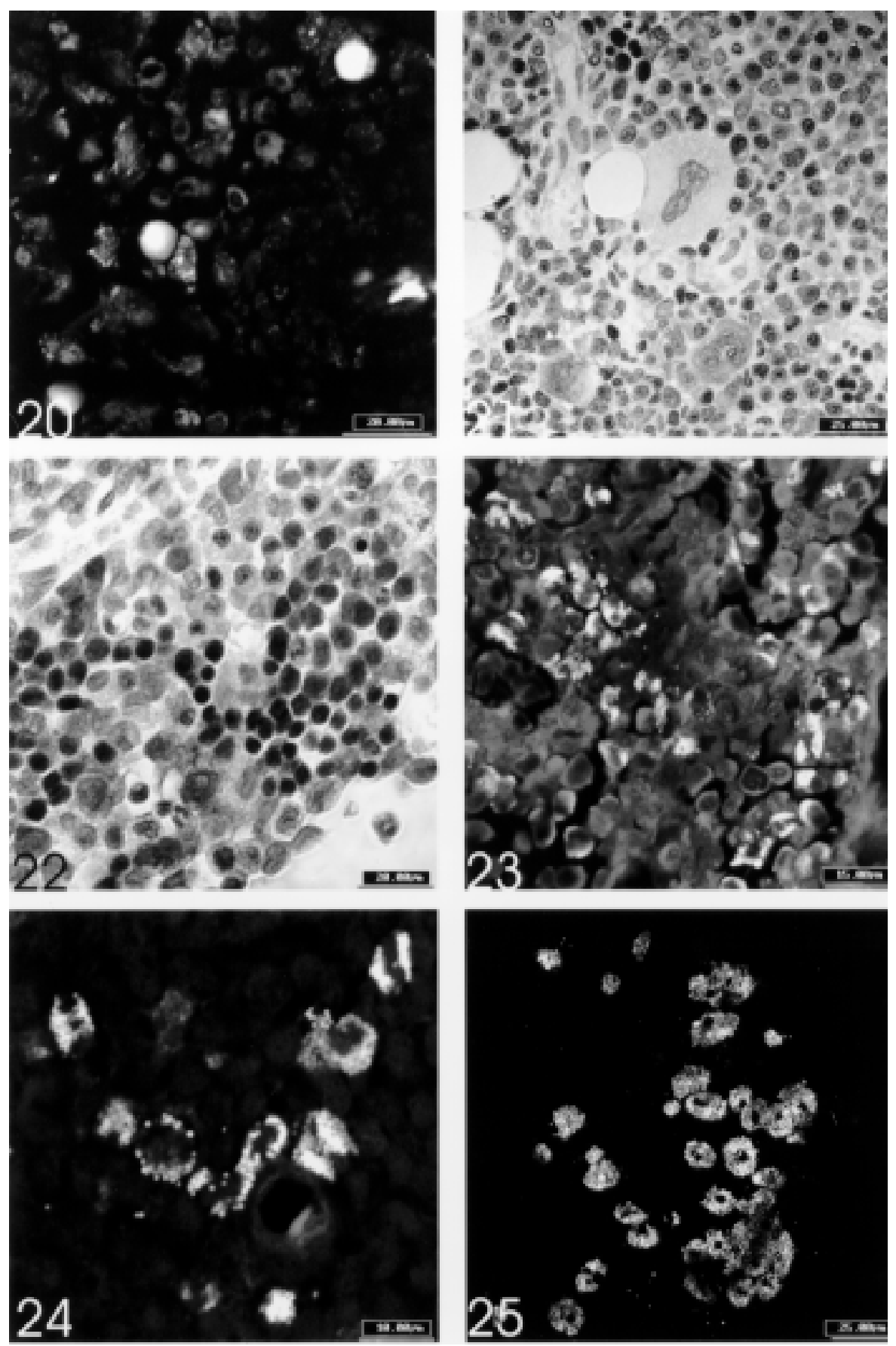

Fig. 20: three round Russell bodies in area of plasmacytosis. Time of infection: 160 days (Masson's Trichrome, CLSM, bar $=20$ $\mathrm{mm})$. Fig. 21: focus of megakaryopoiesis showing megakaryoblast, transitional and mature megakaryocytes. Time of infection: 55 days $(\mathrm{H} \& \mathrm{E}$, bar $=25 \mathrm{~mm})$. Fig. 22: focus of erythropoiesis containing immature and mature erythroblasts, intermingled with macrophages. Time of infection: 90 days $(\mathrm{H} \& \mathrm{E}, \mathrm{bar}=20 \mathrm{~mm})$. Figs 23, 24: foci of eosinopoiesis. Time of infection: 42 days (Fig. 23) and 160 days (Fig. 24) [Sirius red, pH 10.2, CLSM, bar = $15 \mathrm{~mm}$ (Fig. 23); bar = $10 \mathrm{~mm}$ (Fig. 24)]. Fig. 25: large number of connective tissue mast cells. Time of infection: 160 days (Alcian blue-Safranin, CLSM, bar $=25 \mathrm{~mm}$ ). 

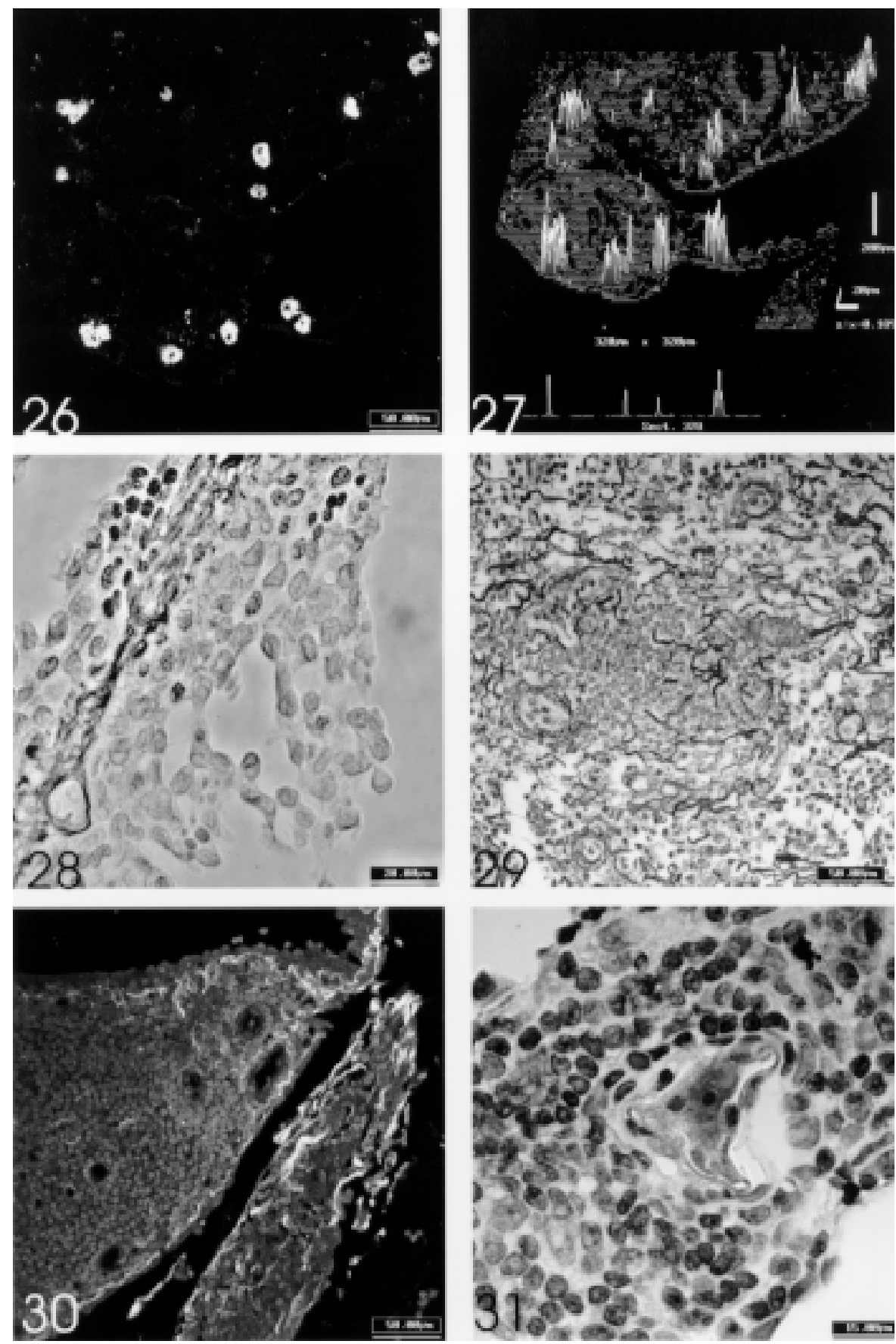

Fig. 26: connective tissue mast cells localized mainly under the mesothelial surface of milky spots (MS). Time of infection: 229 days (Alcian blue-Safranin, CLSM, bar $=50 \mathrm{~mm}$ ). Fig. 27: histogram of Fig. 26, showing peaks corresponding to the mast cells. Fig. 28: mesenteric membrane, close to MS (not present in the picture), showing mesothelial cell hypertrophy and hyperplasia. Time of infection: 90 days $(\mathrm{H} \& \mathrm{E}, \mathrm{bar}=20 \mathrm{~mm})$. Fig. 29: network of MS reticular fibers which is less dense in lymphoid aggregate. Time of infection: 160 days (Gomori's reticulin stain, bar $=50 \mathrm{~mm}$ ). Fig. 30: collagen fibers in less amount than reticular fibers, predominating around vessels and under mesothelial surface. Time of infection: 90 days (PMA-PSR, CLSM, bar $=50 \mathrm{~mm}$ ). Fig. 31 : venula containing a trapped Schistosoma mansoni egg surrounded by lymphocytes and macrophages. Time of infection: 55 days $(\mathrm{H} \& \mathrm{E}, \mathrm{bar}=15 \mathrm{~mm})$ 


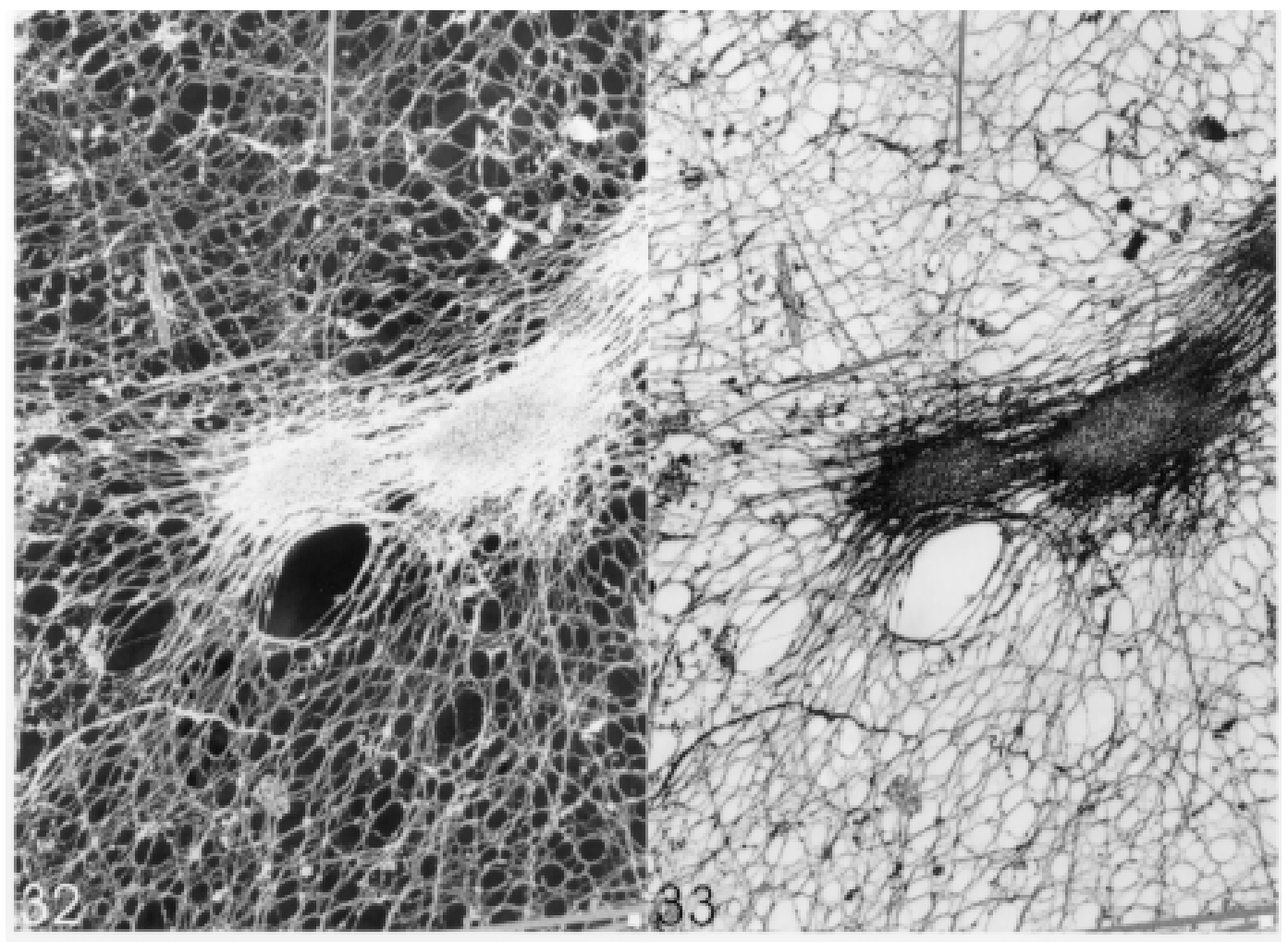

Figs 32, 33: two close milky spots showing high density of fibers that are in continuity with the fibers of the mesenteric membrane stroma. The figures are in positive and negative contrasts (SEM-low vacuum, X 78).

Tested cellular markers for mice yielded negative results, except for IgM and IgG, which presented cross-reactivity with $C$. callosus. Most of omental MS plasma cells were IgM positive (data not shown).

\section{DISCUSSION}

C. callosus presented intense mesenteric and omental reactivity, mainly in MS, during schistosomal infection, as was also demonstrated in mice (Lenzi et al. 1992, 1996). These structures (MS) were mainly of lymphomyelocytic (42 to 90 days) and lymphoplasmacytic (160 days of infection) types, showing frequent presence of lymphoid follicles with germinal centers, plasmacytogenesis and plasmacytosis, mastocytosis, megakaryopoiesis, erythropoesis and less pronounced eosinopoiesis. These results indicate that MS are a preferential site of germinal center-dependent and independent plasmacytogenesis, and a bone marrow-like organ, committed to various cellular lineages (lymphocytes, monocytes/macrophages, megakaryocytes, erythrocytes and eosinophils). MS also appear to be a preferential site, as in rats (Yong et al. 1975, 1977), of mast cells maturation and proliferation. The morphological aspects of lymphocytes and plasma cells, even in the absence of specific cellular markers to characterize different $C$. callosus lymphocyte populations, suggest that their MS produce B1 (plasma cells IgM +) and B2 lymphocytes (local development of germinal centers). Stall et al. (1996) were unable to detect, in mice, any significant involvement of B1 cells in the generation of germinal centers. However, they suggested that the secretion of low affinity IgM antibodies by B1 cells helps to promote the formation of immune complexes which are necessary for the generation of germinal center from conventional B cells. The tendency of $C$. callosus MS to develop germinal center, when stimulated by $S$. mansoni infection, and to present, usually, large number of mast cells, suggests that they react more like rat than mouse MS (Yong et al. 1975, 1977, Mandache et al. 1989). 
The generation of germinal centers are characteristic of B2 lymphocytes and presupposes the presence of follicular dendritic cells. These cells were not identified in human MS (Krist et al. 1995). It is important to point out that the C. callosus MS develop germinal centers more frequently and in large number than in mice, and show less expression of the granulocyte component (eosinophils and neutrophils). C. callosus MS express also more megakaryocytopoiesis and erythropoiesis foci than those of mice. Megakaryocyte and erythrocyte have their own specific lineage factors and require also common growth factors (GM-CSF, IL-3). They are partially influenced by the same cytokines, such as IL-1, IL-7, IL-9, IL-11, and both present receptors to erythropoietin (Miyajima et al. 1992, Metcalf 1993, Foucar 1995). Hirai et al. (1994) demonstrated that erythropoiesis can be induced by intraperitoneal administration of erythropoietin in omental MS in normal mice.

It has been shown that $C$. callosus is a permissive host to S. mansoni (Mello 1979/80) and that it shows a peculiar granulomatous reaction. Its granulomas are usually small and composed by big and mature macrophages, rich in schistosomal pigment (liver) and eosinophils. They contain few lymphocytes and neutrophils, and produce less extracellular matrix than the murine and human granulomas (Lenzi et al. 1995). Intestines and mesenteries of $C$. callosus exhibit a great number of mucosal (MMC) and connective tissue (CTMC) mast cells. This type of inflammatory reaction, based in macrophages, granulocytes and mast cells, suggests that these animals employ an ancestral pattern of cellular response. Studies on the evolution of the immune system, including vertebrates, demonstrated that macrophages, granulocytes and mast cells are related to ancestral phagocytic cells (celomocytes), having gone through all the phylogenetic level of the evolution of immunity (Cooper 1982). On the other hand, schistosomes and their ancestrals had co-evolved with different hosts, from fishes, turtles, dinosaurs and transitional forms of birds, to birds, rodents and hominids (Combes 1990). Therefore, schistosomes had cohabited with animals originated in the Devonian period of the Paleozoic era (300 to 400 millions of years ago). They had the opportunity to live together with animals with only differentiated leucocytes (earlier levels of immunoevolution), or presenting primordial cell-mediated immunity, integrated cell- and humoral antibody immunity and, finally, complex immunoregulation with multiple immunoglobulins classes and subclasses, as well as $\mathrm{T}$ and $\mathrm{B}$ heterogeneous repertoires (Hildemann 1974, Tam et al. 1976). Rodentia order, to which Cricetidae family belongs, ap- peared during the Eocen, an epoch that began 57.8 millions of years ago. Mice originated in the Oligocen (36.6 millions of years ago), and the cricetids in the Miocene (23.7 millions of years ago) (Reig 1984, Storer et al. 1991, Pough et al. 1993).

The CALT constituted of MS is probably ontogenetically derived from splancnopleura (intraembryo AGM) (= aorta (dorsal), genital ridge and mesonephros) (Dzierzak \& Medvinsky 1995), and represents a primordial organ, one that maintains the "phylogenetic memory" of the coelom-associated lymphomyeloid organs. S. mansoni had a long experience of cohabitation with coelomated animals, and can provoke reactivity to CALT, stimulating generation of B1 lymphocytes and of plasma cells producers of IgM of low affinity, towards determinants on both self and microbial antigens (Hardy et al. 1996, Kroese et al. 1996). The B1 lymphocytes constitute a central subset which is tightly connected by network interactions, which gradually expands during the life of a mouse, driven only by idiotypic-anti-idiotypic interactions, and which influences through network connections the repertoire of conventional B-cells and also of Tcells (Mitchison 1992). The consequence of this reactivity between $S$. mansoni and its hosts, like C. callosus, is still unknown and is under investigation. Velupillai and Harn (1994) and Velupillai et al. (1997), demonstrated that lacto-N-fucopentaose III, a sugar found on egg antigens of S. mansoni, contributes to the up-regulation of peritoneal B1 and splenic B cells during the infection. Martins-Filho (1997) detected high level of B1 (CD19+ CD5+) cells in the peripheral blood of patients with acute, intestinal, hepatointestinal, and hepatosplenic states of S. mansoni infection. Dux et al. (1996) found that in naive mice, the proportion of IgM+ CD5+ cells to Thy-1,2 cells shed by omental membrane cultures was nearly the same as in peritoneal cell populations. Shimotsuma et al. (1991) and Krist et al. (1995) investigated the cellular composition of human MS of the greater omentum, and detected that they were composed by $29.1 \%$ and $10.1 \%$ of B lymphocytes, respec-tivelly. This difference in the percentage of B cells was likely to be due to the individuals' ages, functional state and techniques applied (Krist et al. 1995).

Although CALT exists in humans, it is unknown by the majority of pathologists and immunologists. Often, these structures are confounded with unspecific inflammatory infiltrates.

In conclusion, we propose that $C$. callosus, infected with $S$. mansoni, is an additional and interesting model to study the CALT characteristics and reactivity. 


\section{ACKNOWLEDGEMENTS}

To AL de Amorim, FF Cruz, ID Pedro and LFG Caputo for their technical assistance.

\section{REFERENCES}

Bogomoletz W 1980. Avantages de la coloration par le rouge Sirius de l'amyloïde et des éosinophiles. Arch Anat Cytol Pathol 28: 252-253.

Borda CE 1972. Infecção Natural e Experimental de Alguns Roedores pelo Schistosoma mansoni Sambon, 1907, Master thesis, ICB-UFMG, Belo Horizonte, 43 pp.

Brandt A, Schnorr B 1983. Blutgefassversorgung des grossen Netzes von Schaf und Ziege. Z Mikros Anat Forsch 97: 427-440.

Burger E, Miyaji M, Sano A, Calich VLG, Nishimura K, Lenzi HL 1996. Histopathology of paracoccidioidomycotic infection in athymic and euthymic mice: a sequential study. Am J Trop Med Hyg 55: 235-242.

Carson FL, Martin, JH, Lynn JA 1973. Formalin fixation for electron microscopy: a re-evaluation. Am J Clin Pathol 59: 365-373.

Coelho PMZ, Dias M, Mayrink W, Magalhães P, Mello MN, Costa CA 1979. Wild reservoirs of Schistosoma mansoni from Caratinga, an endemic schistosomiasis area of Minas Gerais State, Brazil. Am J Trop Med Hyg 28: 163-164.

Combes C 1990. Where do human schistosomes come from? An evolutionary approach. Trends Ecol Evol 5: 334-337.

Cooper EL 1982. Invertebrate defence systems: an overview, p. 1-35. In N Cohen \& MM Sigel (eds), The Reticuloendothelial System: A Comprehensive Treatise. Phylogeny and Ontogeny, Vol III, Plenum Press, New York and London.

Dolber PC, Spach MS 1993. Conventional and confocal fluorescence microscopy of collagen fibers in the heart. J Histochem Cytochem 41: 465-469.

Dux K, Sobiecka K, Maksymowicz M, Piskorowska J, Skurzak H 1996. Similarities between cells shed by omental milky spots cultured in rotated tubes and cells washed out from the peritoneal cavity of the mouse, p. 7. 6th International Meeting of the Omentum Club, Wolfratshausen/ Germany.

Dzierzak E, Medvinsky A 1995. Mouse embryonic hematopoiesis. Trends Genet 11: 359-366.

Foucar K 1995. Bone Marrow Pathology, ASCP Press, Chicago, 564 pp.

Hamazaki Y 1925. Comparative studies on the milky spots, "taches Laiteuses", of various animals. Folia Anatomica Japonica 3: 243-265.

Hardy RR, Li Y-S, Hayakawa K 1996. Distinctive developmental origins and specificities of the CD5+ B-cell subset. Semin Immunol 8: 37-44.

Hershkovitz PH 1962. Evolution of neotropical cricetine rodents (Muridae) with special reference to the phyllotine group. Fieldiana Zool 46: 1-524.

Hildemann WH 1974. Some new concepts in immunologic phylogeny. Nature 250: 166-129.

Hirai K, Takemori N, Namiki M 1994. Erythropoiesis in mouse omental milky spots induced by erythropoietin: light and electron microscopic study. Int $J$ Exp Pathol 75: 375-383.

Kampmeier OF 1928. Concerning certain mesothelial thickenings and vascular plexuses of the mediastinal pleura, associated with histiocyte and fat-cell production, in the human newborn. Anat Rec 39: 201-208.

Krist LFG, Brower JJE, Eestermans IL, Cuesta MA, Meyer S, Beelen RHJ 1995. Cellular composition of human milky spots. Anat Rec 241: 163-174.

Kroese FGM, Waard R de, Bos NA 1996. B-1 cells and their reactivity with the murine intestinal microflora. Semin Immunol 8: 11-18.

Lennert K 1978. Methodologic prerequisites for a differential diagnosis of lymphomas, p. 73-82. In $\mathrm{Ma}$ lignant Lymphomas other than Hodgkin's Disease, Springer-Verlag, Berlin.

Lenzi HL, Oliveira DN, Borojevic R, Lenzi JA 1992. Milky spots reaction to schistosomal mansoni infection. Mem Inst Oswaldo Cruz 87 (Suppl. V): 111-116.

Lenzi HL, Oliveira DN, Pelajo-Machado M, Borojevic R, Lenzi JA 1996. Coelom-associated lymphomyeloid tissue (milky spots): site of lymphoid and myelomonocytic cell generation. Braz J Med Biol Res 29: 19-24.

Lenzi JA, Mota EM, Pelajo-Machado M, Paiva RAN, Lenzi HL 1995. Calomys callosus: an alternative model to study fibrosis in schistosomiasis mansoni. The pathology of the acute phase. Mem Inst Oswaldo Cruz, 90: 311-318.

Luque EH, Montes GS 1989. Progesterone promotes a massive infiltration of the rat uterine cervix by the eosinophilic polymorphonuclear leukocytes. Anat Rec 223: 257-265.

Mandache E, Negoescu A, Maldoveanu E 1989. The development of lymphatic follicles in the omentum after intraperitoneal stimulation of rats. Morphol Embriol 35: 139-147.

Martins-Filho OA 1997. Análise de Parâmetros Fenotipicos Celulares na Esquistossomose Mansoni Humana, PhD Thesis, Universidade Federal de Minas Gerais, Belo Horizonte, MG, 92 pp.

Massoia E, Fornes A 1965. Nuevos datos sobre la morfologia, distribución geográfica y etoecologia de Calomys callosus callosus (Rengger, 1830) (Rodentia: Cricetidae). Physis 25: 325-331.

Mello DA 1979/80. Infecção experimental de Calomys callosus (Rengger, 1830), (Cricetidae: Rodentia) a quatro espécies de parasitos. Rev Soc Bras Med Trop 13: 101-105.

Metcalf D 1993. Hematopoietic regulators: redundancy or subtlety? Blood 82: 3515-3523.

Mitchison NA 1992. Regulation of the immune response, p. 266-275. In James O’D, Mc Gee, Peter G, Isaacson, Nicholas A, Wright (eds), Oxford Textbook of Pathology, Vol. 1, Principles of Pathology, Oxford University Press.

Mixter RL 1941. On macrophagal foci ("milky spots") in the pleura of different mammals, including man. Am J Anat 69: 159-186.

Miyajima A, Kitamura T, Harada N, Yokota T, Arai K 1992. Cytokine receptors and signal transduction. 
Ann Rev Immunol 10: 295-331.

Pough FH, Heiser JB, McFarland WN 1993. A Vida dos Vertebrados, Atheneu, São Paulo, 839 pp.

Recklinghausen F Von 1863. Uber Eiter und Bindesgewebskörperchen. Virchows Arch Pathol Anat 28: 157-166.

Reig O 1984. Distribuição geográfica e história evolutiva dos roedores muroídeos sulamericanos (Cricetidae: Sigmodontinae). Rev Bras Genet 7: 333-365.

Seifert E 1921. Zur biologie des Menschlichen Grossen Netzes. Arch Klin Chir 116: 510-517.

Shimotsuma M, Kawata M, Hagiwara A, Takahashi T 1989. Milky spots in the human greater omentum: macroscopic and histological identification. Acta Anatomica 136: 211-216.

Shimotsuma M, Takahashi T, Kawata M, Dux K 1991. Cellular subsets of the milky spots in the human greater omentum. Cell Tissue Res. 264: 599-601.

Stall AM, Wells SM, Kong-Peng L 1996. B-1 cells: unique origins and functions. Semin Immunol 8: 45-59.

Storer TI, Usinger RL, Stebbins RC, Nybakken JW 1991. Zoologia Geral, 6a. ed., Nacional, São Paulo, 816 pp.

Strobel S, Miller HRP, Ferguson A 1981. Human intestinal mucosal mast cells: evaluation of fixation and staining techniques. J Clin Pathol 34: 851-858.

Tam MR, Reddy AL, Karp RD, Hildemann WH 1976. Phylogeny of cellular immunity among vertebrates, p. 98-119. In John J Marchalonis, Comparative Im- munology, Blackwell Scientific Publications, Oxford. Trebichavsky I, Holub M, Jaroskova L, Mandel L, Kovaru F 1981. Ontogeny of lymphatic structures in the pig omentum. Cell Tissue Res 215: 437-442.

Vale BS, Pelajo-Machado M, Panasco MS, Lenzi JA, Lenzi HL 1997. Fluorescent stainings for mast cell and eosinophil study by Confocal Laser Scanning Microscopy. Cell Vision 4: 198-199.

Velupillai P, Harn DA 1994. Oligosaccharide-specific induction of interleukin 10 production by $\mathrm{B} 220^{+}$cells from schistosome-infected mice: A mechanism for regulation of CD4 ${ }^{+}$T-cell subsets. Proc Natl Acad Sci USA 91: 18-22.

Velupillai P, Secor WE, Horauf AM, Harn DA 1997. B1 cell $\left(\mathrm{CD}^{+} \mathrm{B} 220^{+}\right)$outgrowth in murine schistosomiasis is genetically restricted and is largely due to activation by polylactosamine sugars. J Immunol 158: 338-344.

Weinberg DF, Baldo-Correa AE, Lenzi HL, Borojevic $\mathrm{R}$ 1992. Schistosoma mansoni: Peritoneal plasmacytogenesis and polypoid transformation of mesenteric Milky Spots in infected mice. Exp Parasitol 74: 408-416.

Yong LC, Watkins S, Wilhelm DL 1975. The mast cell: distribution and maturation in the peritoneal cavity of the adult rat. Pathology 7: 307-318.

Yong LC, Watkins S, Wilhelm DL 1977. The mast cell: II - Distribution and maturation in the peritoneal cavity of the young rat. Pathology 9: 221-232. 
CALT in C. callosus with S. mansoni Infection - Jane A Lenzi et al. 